\title{
Incitement to Genocide against a Political Group: The Anti- Communist Killings in Indonesia
}

\author{
Annie Pohlman, University of Queensland
}

The path to genocide and the eradication of a political group

\begin{abstract}
Cast out this spawn of hell root and branch, tear down the walls of their ideological edifices, plough salt into the sterile sands of their alien mental beachhead, let Communism nevermore sojourn in this Nation. (Djakarta Daily Mail, editorial, 11 December 1965)
\end{abstract}

In 1965 Indonesia's government was overthrown by its military. In the months that followed the military, together with numerous civilian militia groups, eradicated the Left from Indonesia. Through massacres, mass executions, mass arrests and many other forms of grievous human rights abuses, the military and their civilian counterparts effectively wiped out both Leftist ideology and those who supported it. The main victims of these killings and mass arrests were members, or alleged sympathisers, of the mass-supported Partai Komunis Indonesia (PKI, Indonesian Communist Party) and its associated organisations. An estimated 500,000 people were killed during the antiCommunist purges between 1965 and 1968, and more than one million others were rounded up and held in political detention, where many were subjected to torture, starvation and forced labour over many years. ${ }^{1}$

In this article I argue that the Indonesian killings of 1965-1968 constitute political genocide; perhaps the clearest example of genocide against a political group in the twentieth century. By terming the Indonesian killings a case of political genocide, I

\footnotetext{
${ }^{1}$ Please note that small sections of this paper appeared in earlier versions (Pohlman 2010, 2012). For a recent collection of analyses on these events, see Kammen \& McGregor (2012).

PORTAL Journal of Multidisciplinary International Studies, vol. 11, no. 1, January 2014. Stigma and Exclusion in Cross-Cultural Contexts Special Issue, guest edited by Annie Pohlman, Sol Rojas-Lizana and Maryam Jamarani. 
argue two points. The first relates to the exclusion of political groups from the 1948 United Nations Convention on the Prevention and Punishment of the Crime of Genocide (hereafter, the Genocide Convention), hence my examination here and critique of the grounds upon which the exclusion was made. I also outline the political situation in Indonesia prior to the coup and explain how the country went through a process of increasingly violent political pillarisation, effectively creating the conditions for the eradication of the Left. While I argue for the inclusion of political groups within the Genocide Convention, I also question what use such an inclusion would be to the victims of these atrocities.

The second part of my argument pertains to the incitement for the Indonesian killings, which is also an international crime under the Genocide Convention. I contend that the Indonesian military incited the killings through a hate propaganda campaign. As a result of this propaganda, Leftists in Indonesia experienced extreme forms of dehumanisation and social death that, in turn, facilitated their eradication. I examine the propaganda in terms of incitement and culpability on the part of the Indonesian military, and highlight some recent developments in international criminal law on incitement to genocide that may prove instructive in the Indonesian case.

Just as the Indonesian killings are a clear case of political genocide, the Indonesian military's anti-Communist propaganda is a clear case of incitement. This incitement was a causal factor in the mobilisation of parts of the Indonesian population to participate in the eradication of the Left as it facilitated the dehumanisation and social death of Communist Party members and their associates. Philosopher Claudia Card argues that social death is central to genocide because it involves not only atrocities against members of a persecuted group in order to bring about their destruction but also the eradication of that group's 'social vitality'; their social bonds, their intergenerational and community ties and culture. As Card states, 'The very idea of selecting victims by social group identity suggests that it is not just the physical life of victims that is targeted but the social vitality behind that identity' (2003: 76). These extreme forms of persecution are a product of progressively more violent acts, whereby a group of people are gradually isolated and then made targets for increasingly frequent attacks on their livelihoods, rights and then their lives. Essential to this progression towards genocide is the identification and then persecution of a group as well as the incitement to violence 
against its members. In the field of comparative genocide studies, there are a number of studies which examine the progressive 'stages' of the escalation into genocide, such as the models provided by Stanton (1998) and Mayersen (2010: 20-21), each classifying the identification of the persecuted group and measures taken with the intent to incite violence as key steps in the aetiology of genocidal violence.

In the Indonesian case, this progression to genocidal violence took a direct route. The premise for the eradication of the Left in Indonesia was an attempted coup d'état on the night of 30 September 1965. The coup itself, in which six top-ranking generals were kidnapped and killed in the capital, Jakarta, marked the beginning of the campaign against Leftists in Indonesia. The Indonesian military seized the opportunity to destroy its main political rival, the Communist Party, in the resulting upheaval. Within days, parts of the remaining military leadership began a propaganda campaign that incited various religious and nationalist civilian militia groups to join the Army in eradicating Communist supporters. To appreciate the pervasive nature of this propaganda campaign, it is crucial to note that almost all media outlets in Indonesia were either closed or came under the control of the military within only a few weeks following the coup. This effectively meant that the Indonesian military was able to control the public's access to information at the national level. ${ }^{2}$

The propaganda campaign was an elaborate and calculated mixture of stories, warnings and instructions that were spread by radio and in newsprint media. These included intricate tales claiming that the PKI had secretly been planning to take over the country and wipe out non-Communist supporters. Evidence for these plans was provided in entirely false reports of PKI weapons caches, death lists and mass graves allegedly having been dug for the bodies of their enemies. The stories made up about the coup itself, however, featured most prominently within the propaganda. There were allegations that the Generals had been mutilated and tortured by having their eyes plucked out and their genitals sliced off. There were also accusations that members of Communist organisations, particularly those from Gerwani (the women's movement) and Pemuda Rakyat (the youth wing of the PKI), had carried out these sadistic acts of

\footnotetext{
${ }^{2}$ Some of the most prominent newspapers at the time included those under direct military control, such as Angkatan Bersenjata (AB, The Armed Forces), Berita Yudha (BY, Army News), and Duta Masyarakat (DM, Envoy of Society). Other papers central to the propaganda campaign included Sinar Harapan (SH, Ray of Hope), Djakarta Daily Mail (DDT) and Mingguan Berita (MB, Weekly News).
} 
violence, all of which provided further proof of the PKI's immorality and savagery. The significance of these themes was that they created the appearance of the PKI as a dangerous enemy. This, in turn, encouraged those who participated in the elimination of the party's supporters to see themselves as defenders of the nation, purging the Communists from Indonesia in order to save it (Drakeley 2007; Wieringa 1998).

This highly instrumentalised propaganda by the Indonesian military must be seen as a critical impetus to the incitement and perpetuation of the violence against Communists and 'Communist sympathisers' following the 1965 coup. In order to make this argument, however, I must discuss the persecuted group, the PKI and its supporters. The persecution of a sociopolitical group as genocide is a controversial issue within comparative genocide studies. Thus I begin by how and why the attacks against Communists and their sympathisers during the Indonesian killings must be seen as genocide, before examining the case for incitement by the Indonesian military.

\section{The Indonesian killings and genocide}

The PKI have no right to live! ... Hang the PKI! Hang the PKI! Hang the PKI! (Harian Suara Islam, 9 October 1965)

Genocide holds a unique position in both history and international criminal law. It may occur with other crimes, particularly crimes against humanity, but it retains its special position as the crime of crimes in law and as an event of singular importance and resonance in history (Greenawalt 1999: 2293-94). By positioning this discussion squarely within the discourse of comparative genocide studies, a number of immediate ramifications must be addressed when naming the mass killings that took place in Indonesia in 1965-1968 as genocide. The most obvious proceeds directly from longstanding debates over the definition of genocide as set down in Article II of the 1948 United Nations Convention on the Prevention and Punishment of the Crime of Genocide: 'genocide means any of the following acts committed with intent to destroy, in whole or in part, a national, ethnical [sic], racial or religious group.' In relation to the Indonesian case, these debates revolve around the exclusion of 'political' groups from those outlined in the Genocide Convention. I argue that this exclusion is a false one and will demonstrate this using the case of the persecution against Leftist forces in Indonesia since the mid-1960s. To do this, I first take up a point argued by other genocide researchers which is that while genocide is a crime that must remain codified 
and prosecuted as such under international instruments, including the Genocide Convention and the Rome Statute of the International Criminal Court, the concept of genocide often encompasses more than its legal meaning found in court verdicts and juridical settings (Barta 2008: 111).

When exploring the meaning of genocide and, in this case, historiographical understandings of the Indonesian killings, I argue that genocide and its meanings circulate through many discourses and so to barricade them within articles of law, rules of evidence, verdicts and judicial outcomes is, as Tony Barta has put it, 'not very bright ... To restrict historical enquiry to legal rules of evidence makes for the reverse of historical justice. The effect (and sometimes the intention) is injustice; the evidence admitted is partial and inadequate; the complexities of the case are covered rather than elucidated; the history is primitive' (2008: 111). To say that legal discourse and juridical understandings of truth (or evidence or proof) are never impartial but are continuously caught up in their own self-authorising acts of legitimation is nothing new (Derrida 1990; Shildrick 2005). What Barta's comments underline, however, is how the political usages of the strict legal definition of 'genocide' (as a codified crime of the UN Convention, ratified by member states and in the criminal codes of many of these states), have devastating consequences not only for the prevention of genocide but also for its redress. Genocide is, and should remain, a crime that is condemned and punished under international criminal law. But all too often, the legal definition of genocide is, on the one hand, reified so as only to describe those cases of mass human destruction that could be successfully prosecuted as genocide within the jurisprudence of an international criminal tribunal and, on the other hand, used to minimise, trivialise or deny mass atrocities that could not. Put bluntly, genocide denial often masquerades as juridical certitude.

This argument should not be mistaken as a denigration of the legal meaning of the crime of genocide. As with any other crime, the crime of genocide in international or national law is and must be prosecuted within a particular jurisdiction according to the statutes, codes and charters under which it has been defined. I do not argue that the crime in its legal meaning per se be 'lessened'; nor do I support any sensationalist or hyperbolic use of the word 'genocide' (Luban 2006; Saul 2001). The crime of genocide is, at its core, mass atrocities against a group of people who are persecuted on the basis of their 
membership within that group. Such was the case in Indonesia. Hundreds of thousands of people were made targets of mass killing and other forms of mass atrocities because of their membership in, or association with, a particular group. That the victims belonged to an identifiable political group, rather than to 'a national, ethnical [sic], racial or religious group,' means that these acts did not amount to the crime of genocide as per the Genocide Convention. As with many other scholars within the field of comparative genocide studies, I contend that this exclusion of political groups is a false one, premised on a fallacious understanding of how human groups are identified and persecuted during genocides and on the compromises of post-World War II realpolitik (van Schaack 1997).

In the Indonesian case, an additional element to the discussion of political groups and the crime of genocide must be considered. On the one hand, I hold that political groups should be included within the Genocide Convention because their exclusion is based on sophistry and a flawed definition. On the other hand, however, I question the immediate usefulness of this inclusion within the legal definition of genocide, given the extremely small probability that the victims of these crimes will ever obtain any kind of justice in Indonesia. There are currently no judicial avenues being pursued for any criminal or transitional justice mechanisms for the grievous human rights abuses that followed the 1965 coup, therefore, other approaches must be sought, not by default but by necessity. In Indonesia, the likelihood of there being a juridical setting to account for the abuses of 1965-1968 (at least within the lifetimes of those directly involved in those events) appears slim (see ICTJ and KontraS 2011). To restrict genocide's meaning to the crime's legal meaning, therefore, occludes other meanings that may be far more productive in the context of 'coming to terms' with the past.

\section{Groups, victims and the Genocide Convention}

Those who were involved should today be purged, we cannot wait until tomorrow. (Mimber Revolusi, 14 October 1965)

The meaning of genocide in relation to the UN Convention, its definition, prosecution and prevention, has occupied genocide scholars for the last seventy years. Not only have many such scholars created their own definitions of genocide out of dissatisfaction with the Convention, but also amongst these definitions and debates, the inclusion or exclusion of particular groups has remained a centrally contested element of what is 
meant by the term, 'genocide' (Powell 2007; Moses 2002). As Christopher Powell has asked, 'What do genocides kill?' (2007: 527). I do not contribute my own definition of genocide to the plenitude that already exists, rather, by reflecting on how the term and then the Convention came about, I argue that the exclusion of 'political' groups from the Convention's definition of the crime does not exclude the events in Indonesia in 1965-1968 from being genocide.

The work of the jurist who both coined the term and was instrumental in bringing about the Genocide Convention, Raphael Lemkin, has been adopted and interpreted by many on all sides of these definitional debates (Weiss-wendt 2005). Lemkin's writings (1944) about what he understood to be genocide reveal a much more inclusive understanding of the term when compared to how it was defined in the Convention. In his recent book, What is Genocide?, Martin Shaw revisits Lemkin's concept of genocide, and warns that we should gain a better understanding of the man's ideas not because they are the 'last word' on the matter, but because they enable us to see how Lemkin understood (and how we should understand) genocide fundamentally as a process (2007: 17-36). As a much broader concept, for Lemkin, genocide 'signif[ied] a coordinated plan of different actions aiming at the destruction of essential foundations of the life of national groups, with the aim of annihilating the groups themselves' (Lemkin 1944: 79). As Shaw shows, this destruction included a much wider range of acts so as to cover not only the attack on the physical and biological 'aspects of life,' but also on the political, social, cultural, religious and moral 'fields' of the 'captive peoples' (Lemkin 1944: xi-xii, cited in Shaw 2007: 19-20). In essence, many different acts taken separately can be part of genocide, but they are all part of the process of the destruction of human collectivities. This destruction of not only lives but also the social and community foundations gives genocide its unique position as the crime of crimes, and which, according to Card, constitutes the social death of the group (2003: 76).

Lemkin's concept of genocide as a wider process of destruction and how it came to be defined in the UN Convention were separated by time and the political manoeuvring that took place at the end of the Second World War, the beginning of the Cold War, and the establishment of the United Nations. While others have convincingly shown that the eventual wording of the UN Genocide Convention was as much a matter of political compromise as points of law (for example, see Lippmann 1998), I take time here to 
briefly trace some of steps that brought about the exclusion of 'political groups' from the Convention. I echo Beth van Schaack who demonstrates clearly that the "exclusion of political groups from the Genocide Convention represents [a] compromise. No legal principle can justify this blind spot' (1997: 2261).

In the wake of Trial of the Major War Criminals at Nuremberg, at its $55^{\text {th }}$ session on 11 December 1946, the United Nations General Assembly adopted unanimously the following Resolution:

\begin{abstract}
Genocide is a denial of the right of existence of entire human groups ... Many instances of such crimes of genocide have occurred when racial, religious, political and other groups have been destroyed, entirely or in part.
\end{abstract}

The punishment of the crime of genocide is a matter of international concern.

The General Assembly, therefore,

Affirms that genocide is a crime under international law which the civilized world condemns ... whether the crime is committed on religious, racial, political or any other grounds ... ${ }^{3}$

From this original Resolution, the matter then passed through a number of committees, procedural steps and drafts before finally being adopted by the General Assembly on 9 December 1948. The two main drafts were developed in turn by the UN Secretariat (submitted in June 1947) and subsequently by an Ad Hoc Committee on Genocide of the UN's Economic and Social Council (ECOSOC) in mid-1948. In both of these drafts, political groups remained in the definition (Greenawalt 1999: 2273-74). By the end of 1948, however, political groups had been removed from the final Convention. There were purportedly two key reasons for their exclusion: first, political groups were somehow 'unstable' or 'mutable'; and second, including them would be an impediment to many states' willingness to ratify the Convention (LeBlanc 1988: 274-75).

As one researcher put it, the first reason that political (as well as linguistic) groups were excluded from the UN Convention was that they were a 'matter of individual choice' or 'ephemeral,' unlike 'racial, religious, ethnic, and national groups [which ...] were characterised by cohesiveness, homogeneity, inevitability of membership, stability, and tradition' (Lippmann 1998: 455). Seventy years after these debates, which were arguably informed by contemporaneous understandings of individual and group identity, such an argument seems farcical (Cribb 2001, 2003). Ben Saul, who also questions the

\footnotetext{
${ }^{3}$ G.A. Res. 96 (I), 1 GAOR, $1^{\text {st }}$ Sess., $55^{\text {th }}$ mtg. at 188-89, U.N. Doc. A/64/Add. 1 (1947). First and third emphases added (cited in van Schaack, 'The Crime of Political Genocide,' 2263).
} 
exclusion of political groups from the Convention in his study of violence in occupied East Timor, calls the choice of groups currently protected 'illogical.' He rightly adds, 'By protecting only national, racial, ethnical and religious groups from genocide, the Genocide Convention privileges these group identities over others, deeming them somehow more worthy or more fundamental ... This assumption may have held sway in a pre-1950 era ... In the $21^{\text {st }}$ century, however, identity is more fragmented' (2001: 508-9).

This paralogism of protecting only 'stable' groups also plagues current interpretations of the crime. For example, during a number of the trials before the International Criminal Tribunal for Rwanda (ICTR), the question of how to define the Tutsi as a group came under scrutiny. As such, at the first genocide trial of the ICTR, Prosecutor $v$. Akayesu, the Chamber deemed that as the working definition for 'ethnic group' was 'a group whose members share a common language or culture' and, as Tutsi and Hutu share these, the Tutsi could not be characterised as a distinct ethnic group for the purposes of the trial. ${ }^{4}$ However, this was circumvented when the chamber decided to return to the travaux préparatoires of the Genocide Convention and therefore to the idea of protecting "“stable" groups, constituted in a permanent fashion and membership of which is determined by birth' (cited in 'Developments in the Law' 2001: 2014-15). As Paul Magnarella has argued, this effectively meant that 'By adding "stable and permanent group[s]" to the four existing categories, ... the Chamber has significantly expanded the kinds of populations that will be protected by that Convention' (1997: 531). This decision also highlights clearly a number of problems with the current Convention's definition. Most importantly for this discussion, it shows that the definition of group is ambiguous; stability is the condition that qualifies a group for protection yet there are only four specific groups that are themselves unstable. Does this mean that the definition protects any group that can be shown to be 'stable'? And, given that the definition is ambiguous, does this mean that, such as in the Akayesu trial, the definition is open for quite flexible interpretation? While this may mean a more inclusive approach to groups under the Convention, it may also mean inconsistent and ultimately arbitrary judgements ('Developments in the Law' 2001: 2020-24).

\footnotetext{
${ }^{4}$ Case No. ICTR-96-4-T (Int'1 Crim. Trib. For Rwanda Trial Chamber I, 2 September 1998), at $<$ http://www.ictr.org/ENGLISH/cases/Akayesu/judgement/akay001.htm> [Accessed 12 September 2009], cited in 'Developments in the Law: International Criminal Law' (2001: 2014).
} 
The second main argument made against the inclusion of political groups was that the Convention was unlikely to be ratified if they were. When viewed within the context of early Cold War politics, this reason seems the far more likely explanation for the final wording of the Convention. Put simply, in order for the Genocide Convention to become a binding treaty, there had to be at least twenty signatories. Despite the fact that the original Resolution 96(I) condemning genocide was adopted unanimously in 1946, it turned out to be quite difficult to convince twenty states to ratify the Convention. Lemkin himself spent a great deal of time lobbying on behalf of the Convention, so much so that one journalist at the time named him 'the UN's most persistent salesman' (Weiss-wendt 2005: 554). As Samantha Power has shown, Lemkin worked tirelessly, writing to important organisations in each of the member states and, primarily, being sure to appeal to the political interests of the UN delegates (2002: 55). Appealing to so many delegates with particular interests to protect, however, meant compromise; the exclusion of political groups being the most obvious example of this. Particularly at the Sixth Committee meetings prior to the final Convention, several of the delegates made various objections to political groups, for example, on the grounds of not wanting to implicate their own governments in possible genocide allegations or fear that other, politically opposed states, might use the Convention to intervene in internal matters, which would mean 'limitations to their right to suppress internal disturbances. ${ }^{5}$ Given that millions have died under governments during 'states of emergency' or times when 'special powers' have been used to 'suppress internal disturbances,' surely the genocide of people on 'political' or any other grounds is as urgent a call to redress as on the grounds of race, ethnicity, nation or religion?

Two final points make the exclusion of political groups from the legal definition spurious. The first is that many other international conventions (both contemporaneous and subsequent to the Genocide Convention) include them and many other 'groups' that may be persecuted. ${ }^{6}$ The second is that the Convention of 1948 was never meant to be

\footnotetext{
${ }^{5}$ U.N. GAOR $6^{\text {th }}$ Comm., 3d Session, $65^{\text {th }}$ mtg. at 21 (1948) (cited in van Schaak 1997: 2267). See also Weiss-wendt (2005: 551-59), on debates over the inclusion of political groups.

${ }^{6}$ The most obvious of these from around 1948 being Article II of the International Declaration of Human Rights, adopted just one day after the Genocide Convention on 10 December 1948, which states that all people are 'entitled to all the rights and freedoms ... without distinction of any kind, such as race, colour, sex, language, religion, political or other opinion, national or social origin, property, birth or other status.' See also Saul (2001: 505), where he draws attention to the fact that international human rights law has 'recognised the protection needs of a range of increasingly visible group entities,' and notes the
} 
timeless or unchangeable. The beginning of Article II of the Convention actually states: 'In the present Convention, genocide means...' Articles XXIV and XXV of the Convention make clear that it would 'remain in effect for a period of ten years' and 'thereafter remain in force for successive periods of five years' unless a 'request for the revision of the present Convention [is] made at any time by any Contracting Party.' As Norbert Finzsch has argued, the 'framers of the Convention obviously expected political or historical developments that would require altering, in wording or substance, the Convention as it was ratified by the member states of the United Nations. This expectation was not met, because of the effects of the Cold War that lasted for the next 40 years' (2008: 123).

Although the attempt was unsuccessful, this possibility of changing the legal definition of genocide to include additional groups was discussed at the Preparatory Committee on the Establishment of an International Criminal Court (ICC) in the mid-1990s (Saul 2001: 505). In all, the current Convention is ambiguous, flawed, and occasionally a vehicle for genocide denial. This is anathema to the spirit in which it was brought about by Raphael Lemkin, the man who worked so hard and long for its creation. As the Akayesu decision at the ICTR shows, changes will need to be made, so perhaps it is only a matter of time and political will.

\section{Groups, victims and the Indonesian killings}

[The PKI are] poisonous stabbers in the back [who] must be eliminated! (Djakarta Daily Mail, 16 November 1965, cited in Drakeley 2007: 21)

This part of the discussion questions who were the victims, the persecuted 'group', of the Indonesian genocide. The 'political group' of 'suspected Communists and their sympathisers' was a political, cultural, social and economic construct that developed during a period of political 'pillarisation' during the 1950s and 1960s in Indonesia and which, after the coup, became the primary (though not sole) 'category' for persecution (Cribb 2001). Furthermore, the 'suspected Communist or sympathiser' category was defined differently by varying perpetrators. Persecution was the result of many factors, membership within the PKI or its associated organisations being only one of them. In this section I take up the question of 'group' in broad terms because the concept of a 
stable group casts it in a monolithic light when it is precisely the opposite; as with any constructed identity, it was constantly changing, dependent on many variables and, in particular, took on new and lethal meanings when 'suspected Communists' were demonised in the military's propaganda following the coup. Second, by saying that a construct developed during a certain timeframe 'in Indonesia' is misleading; nothing is uniform across Indonesia and what may be said of the southern parts of Central Java would probably not apply to Aceh, eastern Kalimantan or even at times to the northern parts of Central Java. One of the features of the killings was their non-uniformity; just as the killings were different from region to region, so too were the particularities of the victim 'group/s.' Here, I discuss the victim group in more general terms in order to argue that there was a discernable group that, broadly speaking, was persecuted during the massacres - that is, 'suspected Communists and their sympathisers.'

I want now to address the evolution of the 'victim group' in Indonesia prior to the massacres in order to elucidate how fluid the 'group' was and how arbitrary becoming a victim could be. Robert Cribb, the leading scholar on the killings, gives the most useful explanation of how to conceptualise the victim 'group' in his article, 'Genocide in Indonesia, 1965-1966' (2001). Essentially, he underlines the same fallacy of 'stable' and 'unstable' groups (drawing attention to, in particular, the 'rather shallow historical roots' of ethnic identity) and, by sketching a history of colonial and postcolonial Indonesia, clarifies how the idea of an Indonesian 'political' victim group is infinitely complicated by historically competing ideas of the Indonesian 'nation.' The aim of this section is neither to revisit all the debates about the Indonesian nation nor to examine in depth early postcolonial politics (see Anderson 1991; Elson 2008). Rather, given that Cribb's explanation offers a clear and germane understanding of the relevant issues, I take the time to briefly outline his points here.

For Cribb, by the middle of the twentieth century there were three possible 'nations' for the post-Independent Indonesia: 'Within the nationalist movement were three streams of thought, each of them envisaging an independent, modern and prosperous Indonesia, but giving very different content to that nation. These three streams can be labelled Islamic, communist and developmentalist' (2001: 226). While none of these was a united, singular vision for the Indonesian nation, put simply, the country could be based either on Islamic teachings, socialist ideals or, for the developmentalists, it would be 'simply 
turning the formidable apparatus of the state which the Dutch had created in Indonesia to the benefit of Indonesians, rather than foreigners' (2001: 226). By the late 1940s, relations between the three had worsened and, during the 1950s, Cribb contends that 'Indonesia underwent a process of political "pillarisation." In other words, the relatively strong correlation between political and cultural identity was institutionalised, so that each of the identifiable cultural divisions within society was represented not only by its own political parties but by a whole range of separate social institutions' (2001: 228). The Communists, for example, under the leadership of D. N. Aidit, actively pursued building a party that was 'nationwide in scale and [had] a broad mass character, [to be] fully consolidated in the ideological, political and organisational spheres' (cited in Edman 1987: 42). In practical terms, this meant that by the mid-1960s, a broad range of organisations across the political, social, cultural and economic spectrum was associated with the PKI with a claimed following of more than twenty-seven million, although this estimate is considered too high (Mortimer 1974: 366-67).

Indonesia's political pillarisation became more pronounced during the period between 1957 and 1965 when the country's first President, Sukarno, declared martial law and moved Indonesia away from the multiparty parliamentary system of 1950-1957 to 'Guided Democracy.' On the whole, this period is marked by Sukarno's tendencies towards authoritarianism, economic mismanagement and hyperinflation, the curtailment of political parties, and the increase and institutionalisation of the military's influence (Riklefs 1981: 245-71). It was also a period marked by extreme populist rhetoric, led by Sukarno's own cult of personality. His penchant for grand speeches about the continuing, never-ending revolution, national monuments, and anti-imperialistic symbols set the tone both for national politics as well as daily life. As Adrian Vickers has shown:

By the late 1950s most Indonesians ... had been drawn into the political maelstrom. They were exposed to constant political slogans, demonstrations and campaigns, and to sharp divisions in society ... Which side you chose in these divisions determined whether you lived or died, went to prison or gained access to the largesse of the winners in the political leadership struggle ... Indonesian life became dominated by acronyms and abbreviations: [such as] $\mathrm{NASAKOM}^{7}$ [and] MANIPOL-USDEK ${ }^{8}$. Often people did not know what the slogans and acronyms meant, but

\footnotetext{
${ }^{7}$ NASAKOM was an acronym for Nasionalisme, Agama, Komunisme (Nationalism, Religion and Communism).

${ }^{8}$ MANIPOL-USDEK was the acronym derived from Manifesto politik, Undang-Undang Dasar 1945, Sosialisme Indonesia, Demokrasi Terpimpin, Ekonomi Terpimpin, and Kepribadian Indonesia (Political Manifesto, the 1945 Constitution, Indonesian Socialism, Guided Democracy, Guided Economy and Indonesian Identity).
} 
repeated them as mantras of their political groups ... For ordinary Indonesians Sukarno's message had a strong effect. (2005: 145-51)

When Cribb talks about a 'political pillarisation' in Indonesia, a comparison might be made with a similar (though equally problematic) phenomenon, Clifford Geertz's model of aliran, roughly translated as 'streams' of political, social and religious strata (1960; Wertheim 1969). In 1963 Geertz described this political pillarisation of Indonesian life by outlining how the different aliran were organisationally focused around different parties, the Nationalist Party (for Cribb, the 'developmentalists'), the Islamic parties Masyumi and Nahdlatul Ulama (NU) and the PKI:

\begin{abstract}
As well as its political organisation proper, each party has connected with it, formally or informally, women's clubs, youth and student groups, labour unions, peasant organisations, charitable associations, private schools, religious or philosophical societies, veterans' associations, savings clubs, and so forth, which serve to bind it to the local social system. For that reason, each party with its aggregation of specialised associations provides a general framework within which a wide range of social activities can be organised, as well as an over-all ideological rationale to give those activities point and direction. (Geertz 1963: 14)
\end{abstract}

As Andreas Ufen has argued, the 1955 elections made identification with the various aliran stronger and, in turn, increased the rivalries between the parties (2006: 8). While it could not be said that Cribb's communist, developmentalist and religious streams were stable or discrete groups or even that similar groups existed across the diverse contexts of the various regions of Indonesia, it is fair to say that they were identifiable insomuch that Indonesians both identified themselves with these streams and there was clear organisational and institutional membership with them. Furthermore, this identification with the different groups could stretch beyond individuals with particular allegiances to include family members or even entire communities.

The importance of establishing that these groups were identifiable lies in highlighting that membership within these groups was not reducible to a matter of political persuasion. In the newly post-independent Indonesia with a national polity fragmented along ethnic, cultural, religious, economic, linguistic and political lines, membership of these streams or groups was just as (un)stable, malleable and constructed as any of the many ethnic, religious, linguistic or other groups across Indonesia (Young 1990). Put simply, the developmentalist, Islamic and communist streams were groups at that time and, for those who could be/were identified with the 'communist' group following the coup in 1965, this meant potentially lethal consequences. The legal definition of genocide as set down in the UN Genocide Convention aside, it is fair to claim that the 
sociopolitical group that was made the target of the killings and political detentions in 1965-1968 experienced widespread, systematic persecution in such a way as to constitute genocide.

\section{Incitement and culpability}

They must be immediately smashed. Since they have committed treason, they must be destroyed and quarantined from all activities in our fatherland.

(Army Commander, General Nasution, to a gathering of anti-Communist student groups, November 1965. Cited in Hughes 1967: 192-93.)

The second crucial factor in the progression towards genocide is the incitement and mobilisation of perpetrators. Widespread forms of hate propaganda against the targeted group are often necessary to bring about the level of isolation and dehumanisation required to achieve the social death of the group. The highly instrumentalised nature of the Indonesian military's propaganda to incite public participation in the violence is key to understanding the military's overall role in the killings. While a discussion of intent to commit crimes against humanity or genocide on the part of the Indonesian military following the 1965 coup is beyond the purview of this article, it is useful to reflect briefly here on some recent international legal proceedings which speak directly to intent, the use of propaganda and incitement to commit grave human rights abuses. Specifically, the rulings made on the 'Media' trial by the International Criminal Tribunal for Rwanda (ICTR) that found three defendants guilty of incitement to commit genocide (one the editor of a newspaper, the other two broadcasting executives of a radio station) may prove instructive for assigning culpability in the case of the Indonesian military's propaganda in $1965 .^{9}$

As Susan Benesch has argued in reference to incitement of genocide, for incitement to occur, there must be both the intent to cause genocide in addition to the fact that the incitement must be direct and public. Furthermore, she adds that in order for incitement to be proven, the accused 'must have authority or influence over the audience, and the audience must already be primed, or conditioned, to respond to the [accused's] words'

\footnotetext{
${ }^{9}$ The 'Media' trial was, officially, The Prosecutor v. Ferdinand Nahimana, Jean-Bosco Barayagwiza, Hassan Ngeze, Case No. ICTR-99-52-T, Judgement and Sentence, December 3, 2003. The judgements and associated legal documentation may be found on the ICTR website, $<\mathrm{http}: / / \mathrm{www}$.ictr.org $>$. Hereafter referred to as 'Judgement and Sentence.' It should be noted here that 'incitement' and 'hate speech' should not be conflated. See Matas (2000) and Benesch (2008). Incitement is punishable under Indonesian law. For examples, see Articles 160, 161(1 and 2), which refer to the incitement of 'unlawful acts,' in the Criminal Code of Indonesia (Kitab Undang-undang Hukum Pidana, KUHP).
} 
(2008: 493-94). In other words, it is not merely the content of the message given but also the context in which that message is made and who creates that message that determines its potential harm (Schabas 2000: 226-29). As many researchers have shown, the role of hate propaganda is often seen as a sine qua non in the build-up and prolonging of genocide and other mass human rights abuses (Kuper 1991; Staub 1992). Genocides, crimes against humanity and, in this case, mass murder and political incarceration on the scale witnessed in Indonesia after 1965, all require certain levels of planning, coordination, weapons and perpetrators; people do not spontaneously begin killing en masse. Identified as a key element in Gregory Stanton's 'Eight Stages of Genocide,' hate propaganda, in conjunction with social, political and other factors, functions to classify and dehumanise potential victims, polarise communities, and thus aid in the organisation and extermination of those victims (1998). The role played by the Indonesian military's hate-propaganda in 1965 must therefore be examined as a pivotal element for the massacres and mass political detentions that followed.

As in other developing countries at the time, radio and newsprint media were the most accessible and influential sources of information in Indonesia during those months following the coup. As was shown to be the case in the Media trial before the ICTR, the Indonesian military controlled that media and thus used it, as 'the medium of communication with the widest public reach — to disseminate hatred and violence ... [The military] poisoned the minds of [the public], and by words and deeds caused the death of thousands of innocent civilians' ('Judgement and Sentence' 2003: paras. 1099 and 1101). This incitement by the Indonesian military does not, of course, in any way mitigate the criminal liability of those who took part in, planned or collaborated with these crimes (Benesch 2004: 63). What the military's propaganda campaign did do, however, was instrumentally play upon the already charged situation of political and social polarisation of the mid-1960s in Indonesia, and create a fiction of an evil, alien and depraved PKI that had to be destroyed in order to save the nation (Cribb 1990: 2829). Throughout the propaganda campaign following the coup, the messages to 'cleanse' the nation of evil communist forces remained a prominent feature.

Despite the evidence of incitement by the Indonesian military, certain limitations need to be acknowledged. The strength of the case against the Indonesian military is weaker when compared to the Rwandan Media case for numerous reasons. First, the indictment 
of individuals responsible for the creation and dissemination of the propaganda in 1965 is highly problematic. Aside from those high military officials such as Suharto, Ali Murtopo (then chief of Army Special Operations Command, OSPUS) and possibly Brigadier General Sucipto (all now deceased) whose input into the propaganda is most likely, the authorship of the propaganda is unknown. There is an absence of convenient by-lines on news articles to trace individual involvement; most articles only contain the title, text and occasional picture. As Wieringa has argued, the content for these articles, their sources and so on, were all provided by the Indonesian military to the media outlets that remained publishing after the military either closed down or took over in the early days of October 1965 (2002: 296-317). Further obscuring the issue of authorship is the possible role played by US and British intelligence agencies in the creation of the propaganda. As Bradley Simpson has claimed, although access to much information about these governments' involvement remains classified, it is likely that they aided Indonesian military officials in constructing the propaganda (2008: 181). Given that international and Indonesian law requires that individuals and not institutions be held indictable for crimes against humanity and other international crimes such as genocide, and that the individuals concerned in this case are, at present, either deceased or unidentifiable (unless someone were to come forward), this presents the first major impediment to proving incitement on the part of Indonesian military officials.

In terms of the structural preparation of any case against the Indonesian military, there is another obstacle. The Prosecution for the Media case at the ICTR was able to prove incitement on the part of the defendants in two key ways. The first, by creating a 'general atmosphere' or 'climate of harm' of anti-Tutsi sentiment, the defendants' media outlets had promoted a 'message of prejudice and fear [that] paved the way for massacres of the Tutsi population' ('Judgement and Sentence' 2003: paras. 1073 and 243). In the Indonesian case, this media was crucial in creating the 'climate of harm' that incited the massacres. The second way in which the Prosecution in the Rwandan trial was able to prove incitement; however, was also by showing that specific articles/broadcasts resulted in immediate violent actions. As an example of this, it was shown that people identified in the newspaper Kangura would be killed soon after, so that the published names were effectively death lists (Benesch 2004: 66). In the Indonesian military's case, those identified for 'cleansing' are mostly indiscriminately labelled as 'PKI,' 'G30S/PKI elements,' 'Communist sympathisers' or the like. Aside 
from leaders of the PKI or those aligned with the PKI in the parliament, such as D. N. Aidit, Lukman or Subandrio, individuals are rarely named. Therefore proving the causal link between incitement and direct harm to individuals is untenable in the Indonesian case.

The greatest obstacle to preparing a case against the Indonesian military for its propaganda, however, is the persistent recalcitrance on the part of the Indonesian military and government to address past and present state atrocities. In the early years following the downfall of the Suharto regime in 1998, efforts were made to set up a Truth and Reconciliation Commission that would, it was hoped, investigate state crimes committed during that regime, including the mass killings and arrests of 1965-1968. Despite repeated efforts, the Commission was never launched. More recent judicial cases and decisions also do not bode well for the likelihood of Indonesia's military ever being held accountable for their past atrocities. For example, a report into twelve of the trials held before the Ad Hoc Human Rights Court in Jakarta since 2002 for crimes against humanity committed in East Timor by the International Center for Transitional Justice found that the 'inescapable conclusion [was] that the trials on a whole must be regarded as a failure at every level, from technical competence to institutional integrity and political will' (Cohen 2004: ii).' Only six of the eighteen men tried were convicted (receiving sentences of between three and ten years) and all but two of these convictions were overturned or acquitted by the Indonesian Appeals Court in 2004 (Human Rights Watch 2004). In 2012, a three-year investigation into the violence following the 1965 coup was undertaken by the Indonesian National Human Rights Commission (Aritonang 2012). Based on interviews with survivors across the country, the Commission's report stated that there was sufficient evidence to warrant an official investigation by the Attorney General's Office (AGO). The AGO, however, rejected the 850-page report on the grounds that there was insufficient evidence to proceed with an investigation (Prakoso, Sihite, Marhaenjati \& Novialita 2012). The failure of the Truth and Reconciliation legislation added to the apparent unwillingness of the Indonesian government to prosecute grave human rights' violations brings into serious question whether any official investigation into and/or prosecution of crimes committed in the aftermath of the 1965 coup will occur in Indonesia. ${ }^{10}$

\footnotetext{
${ }^{10}$ Other recent cases include the 2005 Appeals Court's acquittal of twelve soldiers convicted in 2004 of the 1984 'Tanjung Priok' massacre of demonstrators in Jakarta (Human Rights Watch 2005), as well as
} 


\section{Conclusion}

It is true that [the PKI] have performed an unpardonable violation; they not only have carried out a diabolical plan but have committed political crimes ... The fate of the state and the nation depend upon the right action being taken. Now is the time for the dissolution of the PKI.

The time for taking action has come.

(Mimbar Revolusi, 11 October 1965)

The social death of the Left in Indonesia following the 1965 coup was achieved through the military's propaganda that, in turn, facilitated their eradication. In this paper I have argued that those eradicated, the PKI and 'Communist sympathizers,' were a defined group identity at the time. Membership of this group was the strongest determinant for persecution during the massacres and mass arrests. Given the underlying flaws of the definition of 'genocide' that excludes the persecution of political groups under the current UN Convention on Genocide, I argue that the Indonesian killings of 1965-1968 should be considered genocide.

Furthermore, despite all of the obstacles to achieving some form of justice for the many who were killed or persecuted, what is clear is that the Indonesian military intentionally sought to incite anti-Communist sentiment and violence following the 1965 coup. Through a deliberate campaign, made of constructed, falsified, intentionally misleading and inflammatory propaganda, the military-controlled media in Indonesia, as in the case of the media producers tried before the ICTR, provided the 'bullets in the gun.' Against a backdrop of heightened social, political and economic tensions, the propaganda was incitement and '[this] trigger had such a deadly impact because the gun was loaded' ('Judgement and Sentence' 2003: para. 953). In other words, just as the ICTR verdict found the defendants guilty of incitement to genocide because of the 'fear-mongering and hate propaganda' contained in their articles and radio broadcasts, so too is the Indonesian military guilty of incitement for deliberately creating and spreading their own hate-filled, demonising propaganda against Communists following the 1965 coup. The fact that it remains highly unlikely that any individuals responsible for that propaganda will ever be brought to trial in Indonesia does not lessen their criminal liability. The media case before the ICTR was a landmark trial in international jurisprudence on incitement and paves the way for further cases to be mounted against those who use words to instill hate and fear in order to incite violence. There is no 
statute of limitations on crimes against humanity and, until the last perpetrator dies, whoever he may be, there is still the possibility that there will be a trial for the incitement of the political genocide in Indonesia.

\section{Acknowledgements}

I wish to thank the two anonymous reviewers of this article whose comments and feedback not only helped to clarify my arguments but also challenged me to think more carefully on the position of the Indonesian killings within the broader field of comparative genocide studies.

\section{Reference List}

Anderson, B. 1991, Imagined Communities. Revised edition. Verso, London.

Aritonang, M. S. 2012, 'Komnas HAM Declares 1965 Purge a Gross Human Rights Violation,' The Jakarta Post, 23 July. Online, available: www.thejakartapost.com/news/2012/07/23/komnas-hamdeclares-1965-purge-a-gross-human-rights-violation.html [Accessed10 September 2012].

Barta, T. 2008, 'With Intent to Deny: On Colonial Intentions and Genocidal Denial,' in 'Documents and Discussion: Responses to Gunter Lewy's Contribution: "Can There be Genocide Without the Intent to Commit Genocide?", Journal of Genocide Research, vol. 10, no. 1: 111-19.

Benesch, S. 2004, 'Inciting Genocide, Pleading Free Speech,' World Policy Journal, vol. 21, no. 2: 62-69. 2008, 'Vile Crime of Inalienable Right: Defining Incitement to Genocide,' Virginia Journal of International Law, vol. 48, no. 3: 485-528.

Card, C. 2003, 'Genocide and Social Death,' Hypatia, vol. 18, no. 1: 63-79.

Cohen, D. 2004, 'Intended to Fail: The Trials Before the Ad Hoc Human Rights Court in Jakarta,' occasional paper series, International Centre for Transitional Justice, New York.

Cribb, R. 1990, 'Introduction: Problems in the Historiography of the Killings in Indonesia,' in The Indonesian Killings of 1965-1966: Studies from Java and Bali, (ed.) R. Cribb. Centre of Southeast Asian Studies, Monash University Clayton, VIC: 1-40. 2001, 'Genocide in Indonesia, 1965-1966,' Journal of Genocide Research, vol. 3, no. 1: 219-39. 2003, 'Genocide in the Non-Western World: Implications for Holocaust Studies,' in Genocide: Cases, Comparisons and Contemporary Debates, (ed.) S. L. B. Jensen, The Danish Centre for Holocaust and Genocide Studies, Copenhagen: 123-40.

Derrida, J. 1990, 'Force of Law: The "Mystical Foundation of Authority,"' trans. M. Quaintance, Cardozo Law Review, vol. 11, nos. 5-6: 919-1045.

Drakeley, S. 2007, 'Lubang Buaya: Myth, Misogyny and Massacre,' Nebula, vol. 4, no. 4: 11-35.

Edman, P. 1987, 'Communism a la Aidit': The Indonesian Communist Party under D. N. Aidit, 19501965. James Cook University, Townsville.

Elson, R. 2008, The Idea of Indonesia: A History. Cambridge University Press, Cambridge.

Finzsch, N. 2008, 'If it Looks Like a Duck, If It Walks Like a Duck, If It Quacks Like a Duck,' in 'Documents and Discussion: Responses to Gunter Lewy's Contribution: "Can There be Genocide Without the Intent to Commit Genocide?," Journal of Genocide Research, vol. 10, no. 1: 119-26.

Geertz, C. 1960, The Religion of Java. University of Chicago Press, London \& Chicago. 1963, Peddlers and Princes: Social Change and Economic Modernisation in Two Indonesian Towns. University of Chicago Press, Chicago.

Greenawalt, A. 1999, 'Rethinking Genocidal Intent: The Case for a Knowledge-Based Interpretation,' Columbia Law Review, vol. 99, no. 8: 2259-94.

Harvard Law Review. 2001, 'Developments in the Law: International Criminal Law,' Harvard Law Review, vol. 114, no. 7: 1943-2073.

Human Rights Watch. 2004, 'Indonesia: Courts Sanction Impunity for East Timor Abuses,' Human Rights Watch, New York, 7 August. Online, available: http://hrw.org/english/docs/2004/08/06/indone9205_txt.htm [Accessed 12 February 2007]. 2005, 'Indonesia: Acquittals Show Continuing Military Impunity,' Human Rights Watch, New York, 12 July. Online, available: http://www.hrw.org/english/docs/2005/07/12/indone11309_txt.htm [Accessed 12 February 2007]. 
International Centre for Transitional Justice (ICTJ) and the Commission for Disappeared Persons and Victims of Violence (Kontras). 2011, Derailed: Transitional Justice in Indonesia Since the Fall of Soeharto - A Joint Report by ICTJ and Kontras. ICTJ and Kontras, Jakarta.

Kammen, D. \& McGregor, K. (eds) 2012, The Contours of Mass Violence in Indonesia, 1965-68. NUS Press, Singapore.

Kuper, L. 1981, Genocide: Its Political Uses in the Twentieth Century. Yale University Press, New Haven.

LeBlanc, L. 1988, ‘The United Nations Genocide Convention and Political Groups: Should the United States Propose an Amendment?', Yale Journal of International Law, vol. 13, no. 2: 268-95.

Lemkin, R. 1944, Axis Rule in Occupied Europe: Laws of Occupation, Analysis of Government, Proposals for Redress. Carnegie Endowment for International Peace, Washington D.C.

Lippman, M. 1998, 'The Convention on the Prevention and Punishment of the Crime of Genocide: Fifty Years Later,' Arizona Journal of International and Comparative Law, vol. 15, no. 2: 415-514.

Luban, D. 2006, 'Calling Genocide by Its Rightful Name: Lemkin's, Darfur, and the UN Report,' Chicago Journal of International Law, vol. 7, no. 1: 303-20.

Magnarella, P. J. 1997, 'Some Milestones and Achievements at the International Criminal Tribunal for Rwanda: The 1998 Kambanda and Akayesu Cases,' Florida Journal of International Law, vol. 11, no. 3: 517-38.

Matas, D. 2000, Bloody Words: Hate and Free Speech. Bain and Cox, Winnipeg.

Mayersen, D. 2010, 'On the Timing of Genocide,' Genocide Studies and Prevention, vol. 5, no. 1: 20-38.

Mortimer, R. 1974, Indonesian Communism under Sukarno: Ideology and Politics, 1959-1965. Cornell University Press, Ithaca.

Moses, D. 2002, 'Conceptual Blockages and Definitional Dilemmas in the "Racial Century": Genocides of Indigenous Peoples and the Holocaust,' Patterns of Prejudice, vol. 36, no. 4: 7-36.

Nababan, A. 2008, 'To Protect the Defenders Doing the Most Possible, Continuing to Do What Has to Be Done,' Netherlands Quarterly of Human Rights, vol. 26, no. 1: 139-48.

Pohlman, A. 2010, 'Propaganda, Misogyny and Incitement to Massacre: The Indonesian Military's Campaign Against Communist Women following the 1 October 1965 Coup,'Analisis Sejarah, vol. 1, no. 1: 1-15.

2012, 'Spectacular Atrocities: Making Enemies during the 1965-1966 Massacres in Indonesia,' in Theatres of Violence: The Massacre, Mass Killing and Atrocity in History, (eds) P. G. Dwyer \& L. Ryan. Berghahn Books, New York: 199-212.

Powell, C. 2007, 'What do Genocides Kill? A Relational Concept of Genocide,' Journal of Genocide Research, vol. 9, no. 4: 527-47.

Power, S. 2002, A Problem from Hell: America in the Age of Genocide. Basic Books, New York.

Prakoso, R., Sihite, E., Marhaenjati, B. \& Novialita, F. 2012, 'AGO Rejects Komnas HAM Report on 1965 Massacres,' 10 November. Online, Available: www.thejakartaglobe.com/archive/ago-rejectskomnas-ham-report-on-1965-massacres [Accessed 10 September 2013].

Ricklefs, M. 1981, A History of Modern Indonesia, c. 1300 to the Present. Macmillan, London.

Saul, B. 2001, 'Was the Conflict in East Timor "Genocide" and Why Does It Matter?,' Melbourne Journal of International Law, vol. 2, no. 2: 477-522.

van Schaack, B. 1997, 'The Crime of Political Genocide: Repairing the Genocide Convention's Blind Spot,' The Yale Law Journal, vol. 106, no. 7: 2259-91.

Schabas, W. 2000, Genocide in International Law: The Crime of Crimes. Cambridge University Press, Cambridge.

Shaw, M. 2007, What is Genocide? Polity Press, Cambridge.

Shildrick, M. 2005, 'Transgressing the Law with Foucault and Derrida: Some Reflections on Anomalous Embodiment,' Critical Quarterly, vol. 47, no. 3: 30-46.

Simpson, B. R. 2008, Economists with Guns: Authoritarian Development and U.S.-Indonesia Relations, 1960-1968. Stanford University Press, Stanford.

Stanton, G. 1998, The Eight Stages of Genocide. Online, available: http://www.genocidewatch.ord/aboutgenocide/8stagesofgenocide.html [Accessed10 March 2013].

Staub, E. 1992, The Roots of Evil: The Origins of Genocide and Other Group Violence. Cambridge University Press, Cambridge.

Ufen, A. 2006, 'Political Parties in Post-Suharto Indonesia: Between Politik Aliran and "Philippinisation",' German Institute of Global and Area Studies Working Papers, no. 37.

Vickers, A. 2005, A History of Modern Indonesia. Cambridge University Press, Cambridge.

Wertheim, W. 1969, 'From Aliran towards Class Struggle in the Javanese Countryside,' Pacific Viewpoint, vol. 10, no. 2: 1017. 
Wieringa, S. 1998, 'Sexual Metaphors in the Change from Sukarno's Old Order to Suharto's New Order in Indonesia,' Review of Indonesian and Malaysian Affairs, vol. 30, no. 2: 143-78. 2002, Sexual Politics in Indonesia. Palgrave MacMillan, New York.

Weiss-wendt, A. 2005, 'Hostage to Politics: Raphael Lemkin on "Soviet Genocide," Journal of Genocide Research, vol. 7, no. 4: 551-59.

Young, K. 1990, 'Local and National Influences in the Violence of 1965,' in The Indonesian Killings of 1965-1966, Studies from Java and Bali, (ed.) R. Cribb. Centre of Southeast Asian Studies, Monash University Clayton, Vic: 101-20. 